\title{
Seed germination and seedling growth of the Mexican sunflower Tithonia diversifolia (Compositae) in Nigeria, Africa
}

\author{
D.A. Agboola, W.F. Idowu \& M. Kadiri \\ Department Of Biological Sciences, University of Agriculture, P.M.B. 2240, Abeokuta, Ogun State, Nigeria; \\ jareagbo@yahoo.com
}

Received 13-VII-2004. Corrected 24-XI-2004. Accepted 14-XI-2005.

\begin{abstract}
We studied seed germination and seedling growth of the Mexican sunflower Tithonia diversifolia in Nigeria. This involved the usage of some dormancy-releasing methods and the effect of some concentrations of three herbicide formulations on the young seedlings. Initial germination tests on fresh and stored seeds revealed a low percentage germination of less than $30 \%$. The seeds of the weed exhibit dormancy. Subjecting the seeds to wet heat at 80 and $100^{\circ} \mathrm{C}$ and light treatment terminated dormancy both in the fresh and stored seeds. Light greatly enhanced the germination percentage of seeds by about $70 \%$. There was gradual increase in germination percentage with increase in storage period in dormancy-released seeds. The mean LAR (Leaf Area Ratio), NAR (Net Assimilation Rate) and RGR (Relative Growth Rate) are comparatively high in young seedlings. Concentrations of $0.5-2.0 \%$ of Gramoxone, Primextra and Galex are toxic to 1 month old seedlings. For eradication, the seedlings should be attacked at one month stage. Rev. Biol. Trop. 54(2): 385-402. Epub 2006 Jun 01.
\end{abstract}

Key words: Tithonia diversifolia, Mexican sunflower, germination, weed, dormancy, herbicide, seedlings growth.

Tithonia diversifolia (Hemsl.) A. Gray, Asteraceae (Compositae), commonly called Marigold, wild sunflower or Mexican sunflower, is a perenial noxious weed of field crops, waste land and road sides. The plant is about $2.5 \mathrm{~m}$ in height at full maturity and reproduce from seeds and from vegetative regrowth of basal stem when cut. It is native to Mexico and the Central Americas where it has been introduced into West Africa as an ornamental plant (Akobundu and Agyakwa 1987).

T. diversifolia is now prominent and fast growing in Nigeria, inhabiting the rainbelt of the southern part of Nigeria especially the south western part and the coastal regions. They also inhabit the wet part of the Guinean savannah especially along the fringes of the rain belt (latitude 6-9 $\mathrm{N}$ ). These areas (Fig. 1) have an annual rainfall of more than 1000 $1250 \mathrm{~mm}$ with an optimum temperature of
28-33 ${ }^{\circ} \mathrm{C}$ (Akobundu and Agyakwa 1987). They line the highways and also occupy the abandoned farmlands adjacent to the highways. The heavy deposits of seeds from the previous year's population which have remained dormant in the dry season (November-March) resumes germination with the onset of the early rain in April-May. The seedlings grow fast and attains maturity during the second rainfall peak of July-August when they flower and seed heavily (Akobundu 1987). The plant dry up before January of the following year yielding a lot of litter, which is often consumed by the fire from the annual bush burning of DecemberJanuary (Agboola 1998).

T. diversifolia has now made an incursion into the farmland thus becoming a nuisance to farmers. The weed produces large biomass which farmers do not fully utilize as green manure in Agronomy. In the highlands of 


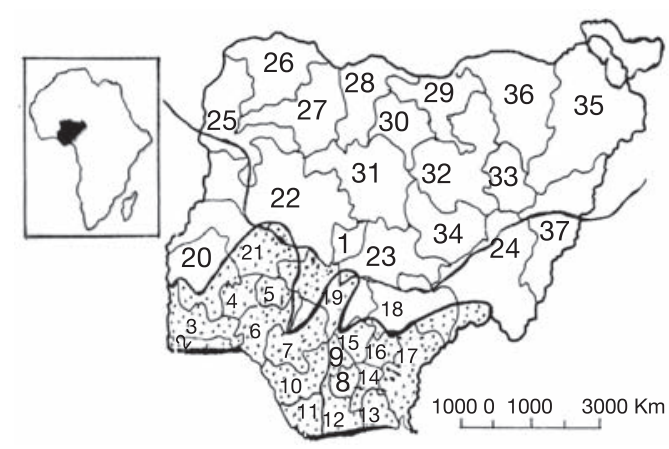

Fig. 1. Map showing areas (shaded) of Tithonia infestation in Nigeria. States with infestation include: (2) Lagos, (3) Ogun, 94) Oshun, (5) Ekiti, (6) Ondo, (7) Edo, (8) Imo, (9) Anambra (10) Delta, (11) Bayelsa, (12) Rivers, (14) Abia, (15) Enugu, (16) Ebonyi, (17) Cross River, (18) Benue, (19) Kogi, (20) Oyo, (21) Kwara, (24) Taraba.

Kenya, the plant is one of those used as traditional hedges to demarcate both external and internal boundaries of farms and compounds. These hedges also protect soil and crops as well as producing fodder, green manure and mulch (Nyasim et al. 1997).

An infusion made from Tithonia leaves and buds is used as a medicine for constipation, stomach pains, indigestion, some throat and liver pains. T. diversifolia ash or solution of fermented extracts have been used to control termite infestation in Agroforestry programmes (Spore 1998).

The vigour and luxuriance of the growth of $T$. diversifolia has stimulated research on the aspects of its biology and the problem posed by this weed (Ayeni and Agbato 1992, Smith and Anisu 1997). This study focuses on dormancy and germination of viable seeds, growth performance and chemical control of young seedlings. This is with a view to contributing to the knowledge about the ecology and physiology of the plant towards a good weed control.

\section{MATERIALS AND METHODS}

Seed collection. The seed collection was made in January 2000 from dead and dried stands on an abandoned farmland separating the fence of the University of Agriculture Abeokuta, Nigeria from the major road. Because of the closeness of the stands, a devise for the collection of the seeds was made. This involved clearing the space infront of the first row of stands with cutlass and spreading a white cotton sheet $(2 \mathrm{~m} \times 3 \mathrm{~m})$ on it. About 2-3 stands were brought together and shaken in such a way that the black 'seeds' which are actually the achenes (dry indehiscent one-seeded fruits characteristic of the Compositae) dropped on the white sheet. The seeds were then gathered together by folding the sheet and cleaned of dried leaves and branches that dropped with them. The 'seeds' were collected and sundried again for 2-3 days and later stored in specimen bottles with cork lids at room temperature $\left(28-30^{\circ} \mathrm{C}\right)$.

Initial germination tests. Germination tests were carried out on freshly harvested seeds using some randomly selected ones according to the methods of (Etejere and Ajibola 1980, Agboola 1996, 1998). One hundred seeds were surface sterilized with $0.1 \%$ mecuric chloride solution for $30 \mathrm{~s}$ and rinsed in several changes of distilled water. They were then placed on moistened filter papers place on $9 \mathrm{~cm}$ Petric dishes. The set up was maintained at $28-30^{\circ} \mathrm{C}$ under a light intensity of 2000 lux as given by four $2 \mathrm{~m}$ Phillip flourescent tubes. Some sets of Petri dishes were wrapped in alluminium foil and incubated in the dark. Each germination test had five replicates. Germination counts were made with the emergence of the radicle to a length of $2 \mathrm{~cm}$ after eight days incubation. The mean values for the percentage germination were calculated.

Dormancy studies. Seed lots of 100 each were soaked in concentrated sulphuric acid for 1 and $5 \mathrm{~min}$. The acid was poured away and the seeds rinsed in several changes of distilled water before placing in Petri dishes. Some seed lots were also immersed in hot water between of $80-100^{\circ} \mathrm{C}$ for $30 \mathrm{~s}$ and $1 \mathrm{~min}$ and they were then cooled in cold weather. A total of 100 seeds from each temperature regime were prepared for germination in the laboratory and 
incubated both in the light and dark. Untreated seeds served as the control. Mean values for the percentage germination were calculated from germination counts from five replicates. The treatment means were compared using the Analysis of variance (ANOVA) at $p \geq 0.05$ and the least significance difference test (LSD).

Effect of storage period on seed germination. Pretreated seeds were sampled monthly from the specimen bottles where they have been stored for germination both in the light and dark for 12 months (January to December 2000). The specimen bottles were corked after each sampling.

Growth Analysis. One to three-month old seedlings of $T$. diversifolia were used for the growth analysis. Dry weights of leaves and whole seedlings were made monthly for three months according to the methods of Beadle (1982) and Agboola (1996). This involved drying the whole plant in the electric oven at $60^{\circ} \mathrm{C}$ for 3 days until a constant weight is got. The leaf areas were also measured. The mean values of these parameters from five replicates were used to calculate three components of growth analysis including the Net Assimilation Rate (NAR), Leaf Area Ratio (LAR) and Relative Growth Rate (RGR).

RGR is calculated from the measured values of the dry weights of plants $\left(\mathrm{W}_{2} \& \mathrm{~W}_{1}\right)$ at different time $\left(t_{2} \& t_{1}\right)$ using the formula:

$$
\mathrm{RGR}=\frac{\log _{\mathrm{e}} \mathrm{W}_{2}-\log _{\mathrm{e}} \mathrm{W}_{1}}{\mathrm{t}_{2}-\mathrm{t}_{1}}
$$

The NAR was calculated from the measured values of leaf area $\left(A_{2} \& A_{1}\right)$, dry weights of values of plant $\left(\mathrm{W}_{2} \& \mathrm{~W}_{1}\right)$ and time $\left(\mathrm{t}_{2} \& \mathrm{t}_{1}\right)$ applying the formula.

$$
\mathrm{NAR}=\frac{\mathrm{W}_{2}-\mathrm{W}_{1}}{\left(\mathrm{~A}_{2}-\mathrm{A}_{1}\right)} \cdot \frac{\log _{\mathrm{e}} \mathrm{A}_{2}-\log _{\mathrm{e}} \mathrm{A}_{1}}{\mathrm{t}_{2}-\mathrm{t}_{1}}
$$

The calculation of LAR was done from the formula

$$
\text { LAR: } \frac{\left(\mathrm{LA}_{1}\right)}{\left(\mathrm{LW}_{1}\right)} \cdot \frac{\left(\mathrm{LA}_{2}\right)}{\left(\mathrm{LW}_{2}\right)}
$$

Using the measured values of leaf area $\left(\mathrm{LA}_{1} \& \mathrm{LA}_{2}\right)$ and dry weights of leaves $\left(\mathrm{LW}_{1} \&\right.$ $\mathrm{LW}_{2}$ ) the mean values from the calculations of NAR, LAR and RGR were used for the graphical interpretation of these growth component over three months.

Effect of herbicides on seeds and young seedlings. Five concentrations $(0.1,0.3,0.6$, $0.9,1$ and $2 \%$ ) each of three commercially formulated herbicide solutions were prepared. The herbicides used include Galex, Gramoxone and Primextra. Hot water Pre-treated seed lots of 100 each were prepared for germination in Petri dishes as earlier described. The various herbicide concentrations were used as soaking solutions while water served as the control. Five replicates of each set-up were made. Germination counts were made at 2-day interval for 10 days. Mean percentage germination were recorded for each treatment.

Five seedlings of $T$. diversifolia were raised in heat-sterilized loamy soils contained in black polythene bags for one to three months. Seedlings in each bag were thinned down to one per bag. Seedlings were divided into seven lots for six herbicide concentrations and water. The various herbicide concentration were tested on the young seedlings by spraying of the foliage leaves using fine-mist sprayer and allowing to dry up. Plants were left in the open for observation. The experimental design was a complete randomized block design with three age groups $\mathrm{x}$ three herbicides x seven concentrations. Data were also subjected to analysis of variance ( $p$ $\geq 0.05$ ) to determine the significant differences between the control and herbicide treatments. 


\section{RESULTS}

The results on the initial germination tests and dormancy studies on seeds of $T$. diversifolia are shown in figures 2 to 5 . Initial germination both in light and dark showed that the seeds do not germinate easily. Less than $30 \%$ germination was observed after five days of sowing (Fig. 2). It was however observed that germination of the few seeds started $24 \mathrm{~h}$ after sowing. There was $10-16 \%$ and $20-25 \%$ germination in seeds exposed to the light and dark respectively (Fig. 2). Seeds treated with concentrated sulphuric acid for 1 to $5 \mathrm{~min}$. and sown in light showed a germination percentage of 20 to 32 after 5 to 7 days of planting (Fig. 3). Sulphuric acid treatment therefore did not

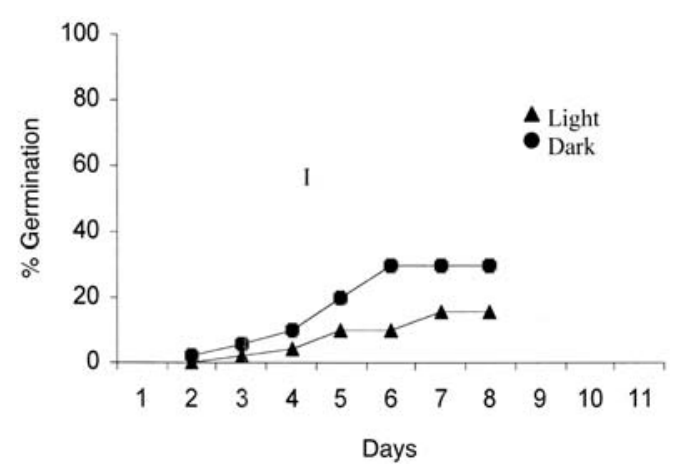

Fig. 2. Percentage of germination of fresh Tithonia diversifolia seeds after 10 days incubation under light and dark. Each point is the mean of five replicates.

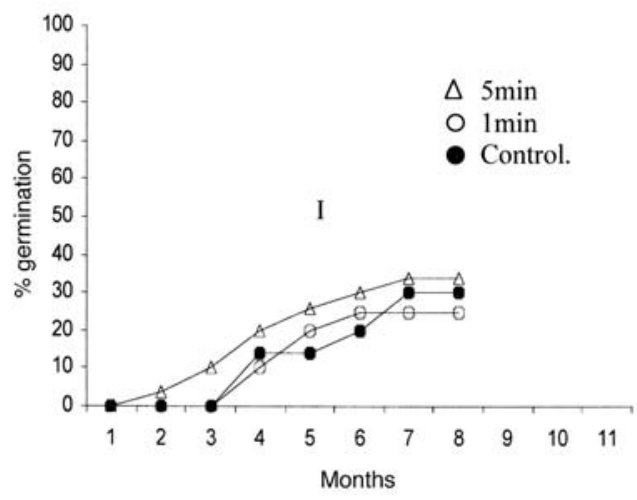

Fig. 3. Percentage of germination of Tithonia diversifolia seeds treated with concentrated sulphuric acid and sown in the light. terminate the dormancy in the seed of this weed specie effectively. Boiling water treatment for 30 to $60 \mathrm{~S}$ at 80 to $100^{\circ} \mathrm{C}$ gave 80 to $85 \%$ compared to $25 \%$ observed in the control (Fig. 4). This gave a high significant effect at $\mathrm{p} \geq 0.05$.

Germination percentage of 80 to 100 was observed in pre-treated seeds of $T$. diversifolia stored for eight to 12 months and light-sown compared to 52 to $5 \%$ in the dark-grown seeds. Light had a significant effect $(\mathrm{p} \geq 0.05)$ on the germination of seeds of $T$. diversifolia. There was a gradual increase in germination percentage with increase in storage period in pretreated seeds (Fig. 5). The results on the growth analysis on one to three month-old seedlings of T. diversifolia are shown in figure 7 to 9 . The mean RGR was 0.19-0.34 $\mathrm{gg}^{-1} \mathrm{month}^{-1}$, mean

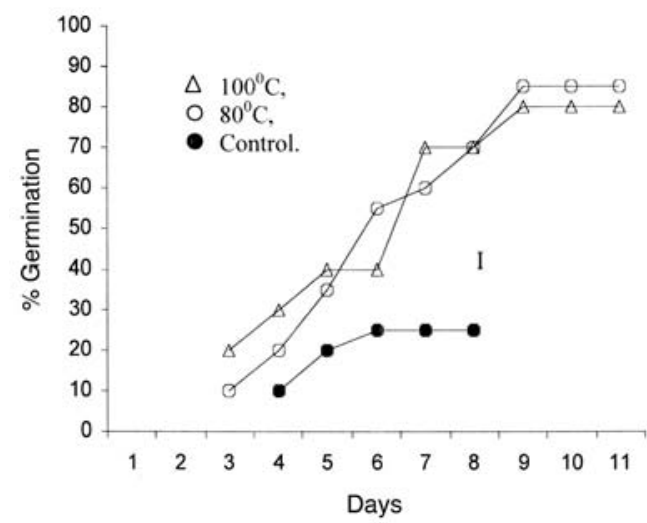

Fig. 4. Percentage germination of Tithonia diversifolia seeds treated with hot water and sown under light. Each point is the mean of five replicates.

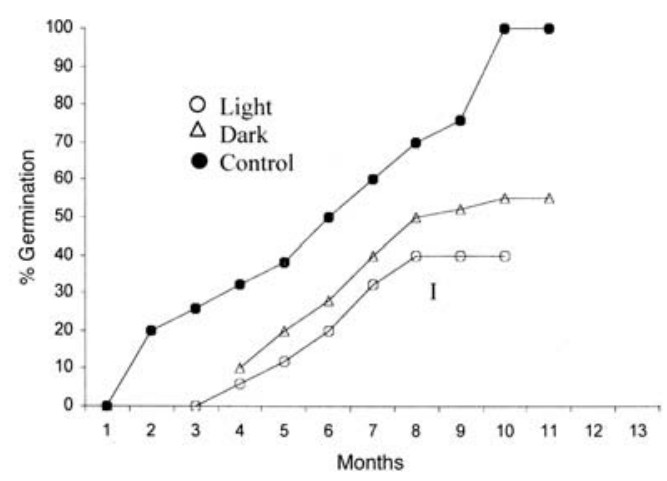

Fig. 5. Percentage of germination of hot water pretreated and twelve months stored seeds of Tithonia diversifolia sown under light. 
LAR 243.68-420.24 $\mathrm{cm}^{2} \mathrm{~g}^{-1}$ and mean NAR $0.52-1.37 \times 10^{-4} \mathrm{gcm}^{-2} \mathrm{month}^{-1}$. It was generally observed that the mean LAR, NAR and RGR are higher in the seedlings especially for the short period of growth.

Observations on the effect of some concentrations $(0.1,0.3,0.6,0.9,1$ and $2 \%)$ of three herbicide formulations on the germination of pretreated seeds are as shown in figure 6. Seeds in 0.1 and $0.3-2.0 \%$ Galex gave $25 \%$ and 2 to $4 \%$ germination respectively while those in $0.1-2 \%$ primextra gave $0-10 \%$ germination (Fig. 6). The effect of the herbicides most especially Gramoxone, on one-month old seedlings caused their rapid death within four days of application. Galex and primextra at $0.5 \%$ concentration was only effective after three days of application as compared to the other whose effect was noticed within $24 \mathrm{~h}$ of application (Table 1). Statistical differences among the three herbicides showed that 0.5 to $2.0 \%$ Gramoxone, 1 to $2 \%$ Galex and primextra
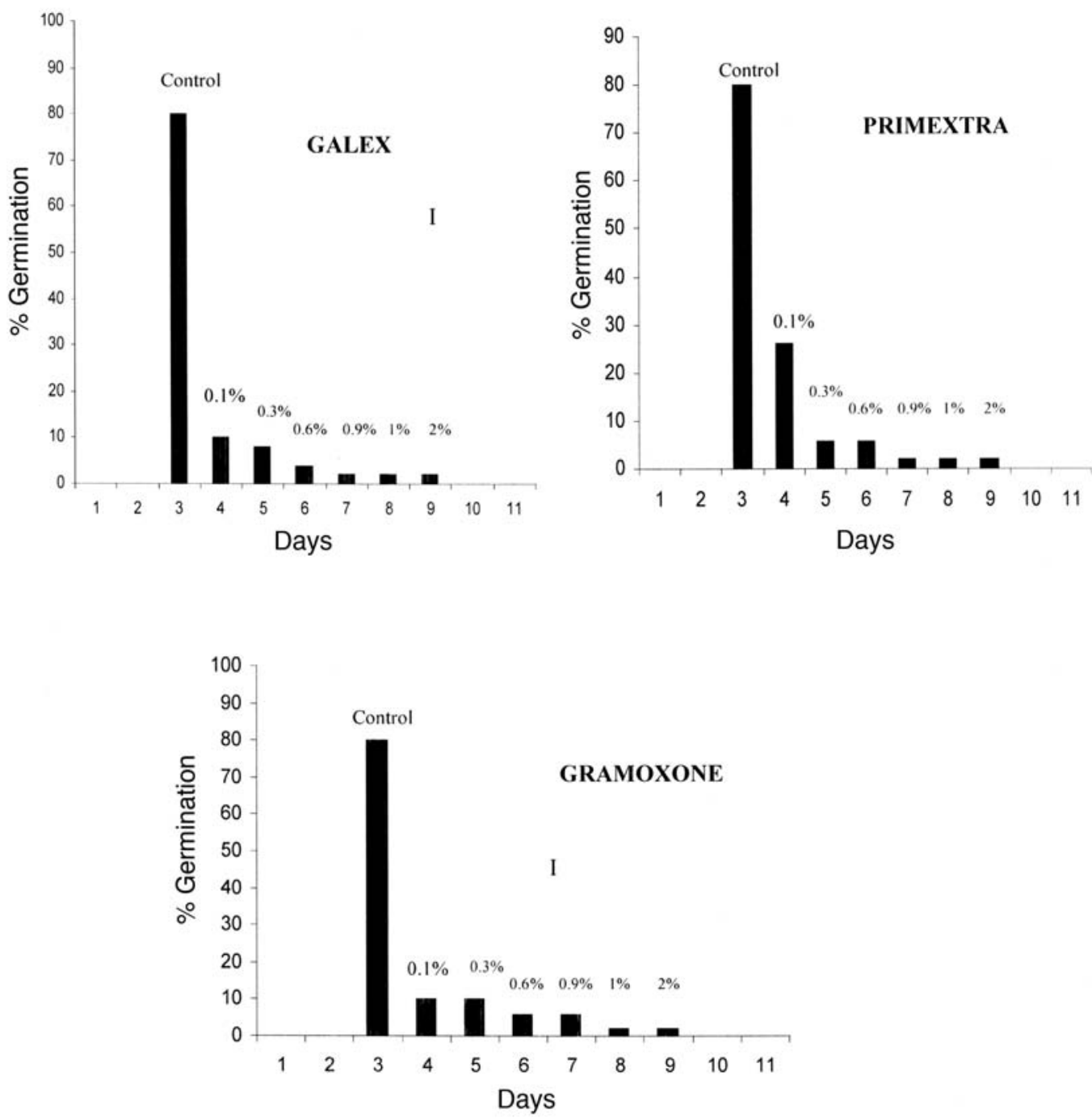

Fig. 6. The effect of some concentrations of three herbicides on the germination of pretreated seeds of Tithonia diversifolia after four days of application. 


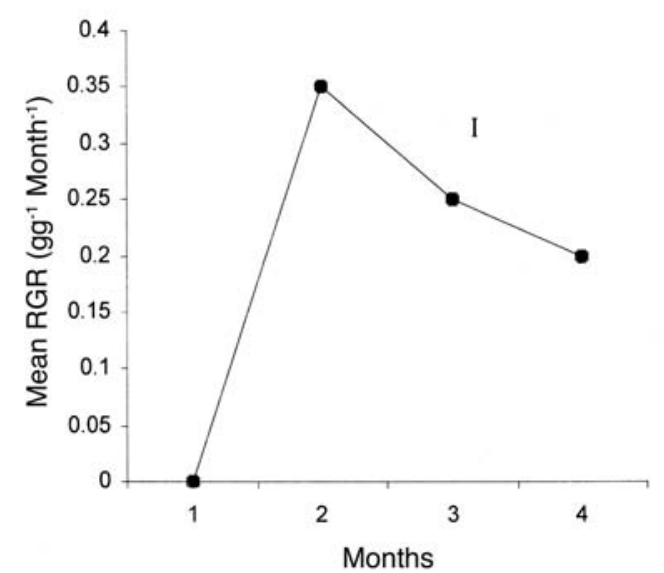

Fig. 7. The Relative Growth Rate (RGR) of 1-3 month-old seedlings of Tithonia diversifolia each point is the mean of five replicates.

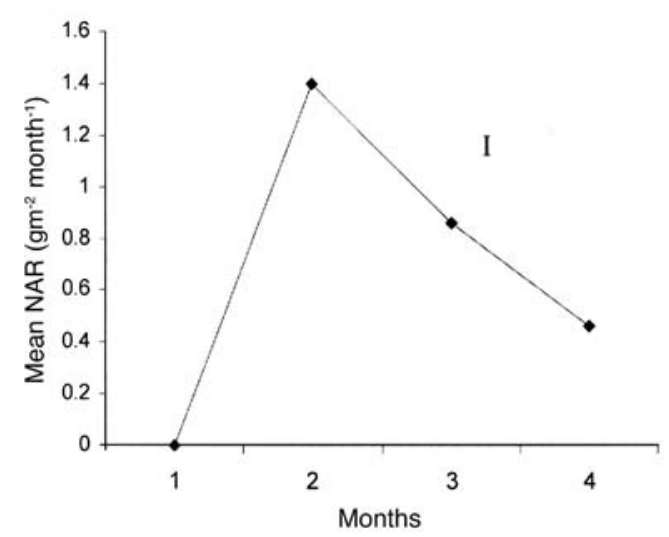

Fig. 8. The Net assimilation rate (NAR) of 1-3 month-old seedlings of Tithonia diversifolia. Each point is the mean of fire replicates.

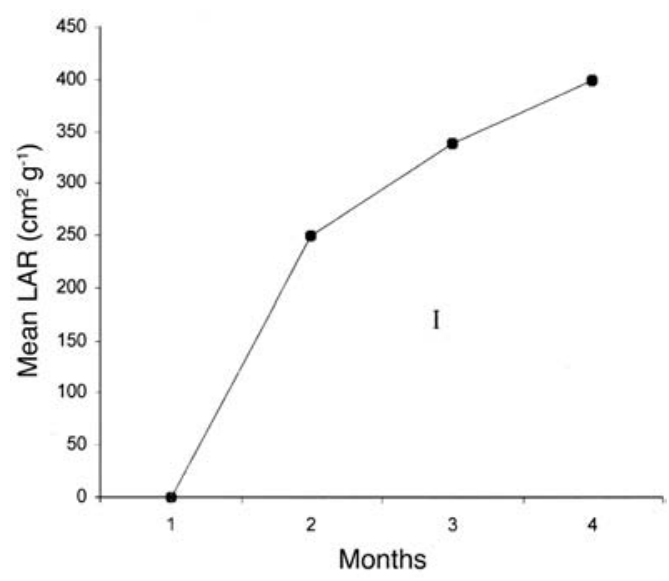

Fig. 9. The Leaf Area Ratio (LAR) of 1-3 month-old seedlings of Tithonia diversifolia. Each point is the mean of five replicates.

had high significant effect $(\mathrm{p} \geq 0.05)$ on the weed seedlings. The effect of some herbicide concentrations on young seedlings of $T$. diversifolia is shown at Table 1 .

\section{DISCUSSION}

Initial germination test showed a low germination percentage in seeds of $T$. diversifolia. The seeds exhibit dormancy and required pretreatment for best germination result. Etejere and Ajibola (1990), Agboola (1998) also observed such situation in seeds of Rotboella cochinchinensis, Calapogonium mucunoides, Cassia hirtusa and Cassia obtusifolia some of

TABLE 1

Percentage of seedlings of T. diversifolia alive at three different herbicide concentrations (\%)

\begin{tabular}{|c|c|c|c|c|c|c|c|c|c|}
\hline \multirow[b]{2}{*}{ Days } & \multicolumn{3}{|c|}{ Gramoxone } & \multicolumn{3}{|c|}{ Galex } & \multicolumn{3}{|c|}{ Primextra } \\
\hline & 0.5 & 1.0 & 2.0 & 0.5 & 1.0 & 2.0 & 0.5 & 1.0 & 2.0 \\
\hline 1 & $* 0.0$ & $* 0.0$ & $* 0.0$ & $90.0 \pm 4.2$ & $* 0.0$ & $* 0.0$ & 100 & $* 0.0$ & $* 0.0$ \\
\hline 2 & $* 0.0$ & $* 0.0$ & $* 0.0$ & $82.0 \pm 3.4$ & $* 0.0$ & $* 0.0$ & $64.0 \pm 3.6$ & $* 0.0$ & $* 0.0$ \\
\hline 3 & $* 0.0$ & $* 0.0$ & $* 0.0$ & $60.5 \pm 2.1$ & $* 0.0$ & $* 0.0$ & $* 0.0$ & $* 0.0$ & $* 0.0$ \\
\hline 4 & $* 0.0$ & $* 0.0$ & $* 0.0$ & $* 0.0$ & $* 0.0$ & $* 0.0$ & $* 0.0$ & $* 0.0$ & $* 0.0$ \\
\hline
\end{tabular}

Data are means of five replicates. * Significant $(\mathrm{p}>0.05) . \quad$ LSD $=2.46$ 
which are serious weeds of wastelands corn, cowpea and sorghum in Nigeria. Seed pretreatment such as hot water abolished dormancy in their seeds. The pretreatments that terminated dormancy in seeds of $T$. diversifolia in this study (i.e. combination of heat, light and storage) showed that the seeds suffer from physiological dormancy. This is also true of seeds of prickly sida, Sida spinosa (Baskin and Baskin 1984) and centro, Centrosema pubescens (Omokanye and Onifade 1993). Seeds from many weed species are subject to dormancy of many kinds causing delayed germination of variable duration. All these are to the ecological advantage of the establishment of the weeds in their habitats (Kolk 1979). Heat treatment in the case of $T$. diversifolia seeds had helped to cause some metabolic changes within the dormant seeds. The ability of the embryo to germinate appears only when seeds have undergone warm stratification (Nikolaeva 1980, Esenewo and Adebona 1990).

Light significantly enhanced the germination of seeds of $T$. diversifolia seeds usually germinate to a lightly higher percentage in light than in the dark (Li et al. 1999). Photoblastic seeds will germinate better in the open than under the forest canopy (Olatoye 1965). In the open, solar radiation comes unhindered, moreover associated with this increase, is the air and soil temperature. This best explain the luxuriant growth of the seedlings of $T$. diversifolia in the open by the road sides especially along the highways at the onset of the rainy season (April-May) in Nigeria.

Percentage germination increased with increase in storage period in pretreated seeds than in the non-treated ones. The seeds of T. diversifolia seem to require some after-ripening period which allows for embryo maturation. According to Li et al. (1999) maturation seem to be a pre-requisite for seeds to respond and germinate.

The mean LAR, NAR and RGR are high in the young seedlings of $T$. diversifolia. This shows that the weed specie is a fast growing type. Smith and Anisu (1997) observed a rapid early vegetative growth especially in plant height and leaf production of $T$. diversifolia between 6-12 weeks. The growth rate of plants have been found to be dependant on the effectiveness of the leaf area. This is not far-fetched as the leaf is the major assimilatory surface (Black 1972, Hunt 1978).

Gramoxone, Primextra and Galex at 0.5 to $2.0 \%$ and 0.3 to $2 \%$ concentration were effective in suppressing the germination and growth of seeds and seedlings respectively. So many herbicide formulations have been tried on some noxious weeds including Chromolaena odoratum (Eupatorium odoratum) and there have been appreciable success with low concentration of the herbicides (Etejere 1980). Herbicides have been known to distrupt the enzyme systems thus affecting the entire physiology (including respiration, chlorophyl formation and photosynthesis) of the living system (Akobundu 1987). A good approach to the problem of eradication of this noxious weed is to find useful application such as in Kenya where $T$. diversifolia is used as green manure and for medicinal purposes (Nyasim et al. 1997). It is suggested that for eradication, the seedlings should be attacked at one month stage. By this time all viable seeds that must have been naturally heat-treated by the dry season would have germinated.

\section{ACKNOWLEDGMENT}

The authors acknowledge the help of the final year Botany students of 1999/2000 academic session during the seed collection, $\mathrm{M}$. Jagun the chief farm Manager, University of Agriculture, Abeokuta, Nigeria for the herbicides and Modupe Bolarinwa for assistance with the manuscript.

\section{RESUMEN}

Se estudió la germinación y crecimiento de las plántulas del girasol mexicano Tithonia diversifolia. Se usaron métodos de periodo de latencia y germinación, y el efecto 
de varias concentraciones de tres herbicidas sobre las plántulas jóvenes. Las pruebas iniciales de germinación con semillas frescas y almacenadas revelaron un bajo porcentaje de germinación (30\%). Las semillas de malezas permanecieron latentes. Al someter las semillas a tratamientos de calor húmedo de 80 y $100^{\circ} \mathrm{C}$ y luz se terminó con el periodo de latencia en las semillas frescas y en las almacenadas. La luz aumentó el porcentaje de germinación a cerca del 70\%. Hubo un incremento gradual en el porcentaje de germinación en el periodo de almacenamiento en las semillas salidas de la latencia. Los promedios de cociente de área foliar, tasa neta de asimilación y tasa de crecimiento relativo son comparativamente altos en las plántulas jóvenes. Las concentraciones de $0.5-2.0 \%$ de Gramoxone, Primextra y Galex son tóxicas para las plántulas de un mes de edad.

Palabras clave: Tithonia diversifolia, girasol mexicano, germinación, malezas, periodo de latencia, herbicidas, crecimiento de plántulas.

\section{REFERENCES}

Agboola, D.A. 1996. Studies on the effect of seed size on germination and seedling growth of three tropical three species. J. Trop. Forest Sci. 9(1): 44-51.

Agboola, D.A. 1998. Dormancy and seed germination in some weeds of tropical wastelands. Nigerian J. Bot. 11: 79-87.

Akobundu, I.O. 1987. Weed science in the tropics principles and practices. Wiley, New York. p. 207-244.

Akobundu, I.O. \& C.W. Agyakwa. 1987. A handbook of West African weeds. International Institute of Tropical Agriculture (I.I.T.A) Ibadan, Nigeria. 194 p.

Ayeni, A.O. \& S.O Agbato. 1992. Influence of planting depth on the control of Mexican flower, Tithonia diversifolia. 20th Annual Conference, Weed Science Society of Nigeria. $32 \mathrm{p}$.

Baskin, J.M. \& C.C. Baskin. 1984. Environmental conditions required for germination of prickly sida (Sida spinosa). Weed Sci. 32: 786-791.

Beadle, C.L. 1982. Plant growth analysis. p. 19-25. In S.J. Coomb \& D.O. Hall (ed.). Techniques in Bioproductivity and photosynthesis, Pergamon, Oxford, England.
Black, M. 1972. Control processes in germination and dormancy. In J.J. Head \& E. Lowesten (ed). Oxford Biology Readers. Oxford, England.

Etejere, E.O. \& I.O. Ajibola 1990. Studies on seed germination and dormancy of Itch grass (Rottboellia cochinchinensis). Weed Sci. 3: 19-28.

Etejere, E.O. \& I.O. Ajibola. 1980. Viability of herbicidetreated seeds of Eupatorium odorantum L. Weed Res. 20: 361-363.

Esenewo, C. \& A.C. Adebona. 1990. Effect of high temperature pretreatment on the germination of Corypha umbraculifera seeds. Nigerian J. Bot. 3: 85-91.

Hunt, R. 1978. Plant growth analysis studies in Biology series. No. 96. Edward Arnold, London. p. 8-25.

Kolk, H. 1999. Weed Seeds, p. 9-11. In Advances in research and technology of seeds part 4: CTA, Wagenigen, Nerthelands.

Li, X., J.M. Baskin \& C.C. Baskin. 1999. Physiological dormancy and germination requirements of seeds of several North American Rhus species (Anacardiaceae). Seed Sci. Res. 9: 237-245.

Nikolaeva, M.G. 1980. Factors controlling dormancy pattern, p. 119-126. In A.A. Khan (ed.). Physiology and Biochemistry of seed dormancy. North Holland, New York.

Nyasim, M., A. Niang, B. Amadalo, E. Obonyo \& B. Jama. 1997, p. 1-11. Using the wild sunflower, Tithonia, in Kenya for soil fertility and crop yield improvement. ICRAF, Kenya.

Olatoye, S.T. 1965. The effect of light, prechilling and gibberellic acid on the germination of Chlorophora excelsa and Chlorophora regia. Nigerian J. Agri. 2: 71-74.

Omokanye, A.T. \& O.S. Onifade. 1993. Effect of storage and scarification time on seed germination of Centro (Centrosema pubescens). Seed Res. 20: 11-15.

Smith, M.A.K. \& O.O. Anisu. 1997. Some aspects of the Biology of Mexican sunflower Tithonia diversifolia. Nigerian J. Weed Sci. 10:1-5.

Spore, C.T.A. 1998. Tithonia spells trouble for farmers. Bulletin of the center for Technical Agriculture, Wagenigen, Netherlands. 6 p. 